\title{
First Record of Partial Albinism and Scoliosis in Odontophrynus occidentalis Tadpoles (Anura: Cycloramphidae).
}

\author{
Eduardo Alfredo Sanabria*, Lorena Beatriz Quiroga and Alejandro Laspiur \\ Departamento de Biologia; Instituto y Museo de Ciencias Naturales; Facultad de Ciencias Exactas, Físicas y \\ Naturales; Universidad Nacional de San Juan; Av. España 400 (N); C.P.: 5400; San Juan - Argentina
}

\begin{abstract}
Albinism has been widely reported for diverse group of vertebrates. However, scoliosis is a rare abnormality. In this work, the first record of partial albinism and scoliosis case in tadpole of the frog Odontophrynus occidentalis is being presented. The individual was captured in Quebrada de las Flores, Sierra Pie de Palo, Caucete Department, San Juan Province, Argentina.
\end{abstract}

Key words: Albinism, Scoliosis; Odontophrynus occidentalis; San Juan; Argentina

\section{INTRODUCTION}

The albinism is a rare congenital and inherited condition that is characterized by an alteration in the function of dermal pigment via recessive allele expression. Phenotypically, this condition is expressed as an absence or reduction of melanin of the skin, eyes, or hair. A complete lack of melanin produces a condition known as total albinism, but when vestiges of melanin are retained, the condition is termed partial albinism (Klug \& Cummings, 1999). Total albinism has been widely reported among the major vertebrates lineages, including cartilaginous fishes, Mustelus schimitti (Teixeira \& Araújo, 2002), Rhinoptera bonasus (Schwartz, 1959), Dasyatis americana (Schwartz \& Safrit, 1977), Notorynchus maculatus, Raja clava, R. naevus, R. batis (Nakaya, 1973) and snakes: Storeria occipitomaculata (Watkins-Colwell, 2002) and Lampropeltis triangulum (Mitchell \& McGranaghan, 2004). Partial and total albinism has also been reported in the snakes, Coluber logissimus, Coronella austriaca, Tropidonotus natrix (Boulenger,
2000), and partial albinism in the worm lizard Blanus cinereus (Malkmus, 1997). In amphibians, this abnormality has been reported for the salamander Ambystoma opacum (Mitchell \& Church, 2002) and Triturus marmoratus (Diego-Rosilla et al., 2007), and in frogs such as Lithobates pipiens (Federighi, 1938) and Lithobates catesbeianus tadpoles (Mitchell, 2005). Scoliosis is a deformation of the spinal column caused by a combination of genetic and epigenetic events that alter the germinal tissues (Hardy, 1964). In amphibians, this deformity is rare, and to has only been observed in Lithobates pipiens tadpoles (Hardy, 1964). In this paper the first record of albinism and scoliosis in a tadpole of Odontophrynus occidentalis is being presented, which represents the first cases of these deformities for the Argentine herpetofauna.

\section{MATERIALS AND METHODS}

On 19 January 2007 in the course of a faunal survey of Quebrada de las Flores, Sierra de Pie de Palo, Caucete

*Author for correspondence: sanabria.eduardoa@gmail.com 
Department, San Juan Province, Argentina, an Odontophrynus occidentalis tadpole (IMCN-UNSJ 5094) were collected. The climate at this locality is arid with spring precipitation ( $80 \mathrm{~mm}$ per year) and marked thermal amplitude. The mean maximum temperature is $25.7^{\circ} \mathrm{C}$ and the mean minimum temperature is $10.4^{\circ} \mathrm{C}$. Predominant vegetation is xeric including desert shrubs such as Prosopis flexuosa, Larrea cuneifolia, $L$. divaricata, and cacti such as Opuntia sulphurea, Tephrocactus articulatus, and Cereus aeithiops (Cabrera, 1994).

\section{RESULTS AND DISCUSSION}

The tadpole collected was at developmental stage 41 (Gosner, 1960), $86 \mathrm{~mm}$ total length and $34.8 \mathrm{~mm}$ maximum width (digital calliper to nearest $0.1 \mathrm{~mm}$ ). This specimen differe from typically pigmented tadpoles of this species in having a whitish-yellow body. However, this tadpole's eyes were normally pigmented, indicating a case of partial albinism. The normal dorsal coloration of $O$. occidentalis tadpoles is dark brown or olive-green with a transparent ventral body area (Gallardo, 1987).

Albinism occurs as a result of gene alterations, which are predominantly inherited from the parents. Albinism occurs in several forms. It can be inherited when the alleles are autosomal and recessive, autosomal and dominant, or ligated. The Sierra de Pie de Palo $O$. occidentalis population is very isolated and restricted to a shallow stream with a widely fluctuating water volume that is surrounded by desert. If albinism was more prevalent in this population, the expression of this recessive gene might be explained by this isolation and potentially low genetic flow. Most likely, however, this specimen represents a single rare mutation in an otherwise normal population. Scoliosis is caused by an interaction between genes and the environment. Low oxygen and the presence of metals at oviposition sites may cause scoliosis in larval fishes and amphibians (Unrine et al., 2004). The eggs of O. occidentalis are depostited individually on the bottom of shallow streams. If this condition was common in this population, it might be explained by the small effective population size and inbreeding, but more likely this represented a mutation that arose during the development of this individual, perhaps as a result of its lack of body pigmentation.

\section{ACKNOWLEDGEMENTS}

We thank to Robert Espinoza for comments and English review. To Sebastian Quinteros and the reviewers for the criticize that helped to improve this work.

\section{REFERENCES}

Boulenger, G.A. (2000), The snakes of Europa. Electronic reprint by Arment Biological Press. London.

Cabrera, A.L. (1994), Enciclopedia Argentina de Agricultura y Jardinería, Tomo II, Regiones Fitogeográficas Argentinas. ACME S.A.C.I. Buenos Aires, Argentina.

Diego-Rasilla, F. J., Luengo, R. M. \& Rodríguez-García, L. (2007), Triturus marmoratus (Marbled Newt). Limb abnormalities. Herpetological Review, 38 (1), 68.

Federighi H. (1938), Albinism in Rana pipiens Shreber. Antioch College, Ohio. 38, 37-40.

Gallardo, J.M. (1987), Anfibios de Argentina, Guía para su Identificación. Biblioteca Mosaico, Buenos. Aires, Argentina.

Gosner, K.L. (1960), A simplified table for staging anuran embryos and larvae with notes on identification. Herpetologica. 16, 183-190.

Hardy J.D. (1964), The spontaneous occurrence of scoliosis in tadpole of the Leopard Frog, Rana pipiens. Chesapeake Science, 5, 101-102.

Klug, W. S., Cummings, M. R. (1999), Conceptos de Genética. Prentice - Hall, Madrid.

Malkmus, R. (1997), Partial albinism in the mediterranean worm lizard, Blanus cinereus (Vandelli, 1797) in Portugal (Reptilia: Amphisbaenidae). Sauria, 19, 31-34.

Mitchell J.C. (2005): Albinism in american bullfrog (Rana catesbeiana) tadpoles from Virginia. Banisteria, 25, 51.

Mitchell J.C., Church, D.R. (2002), Leucistic Marbled Salamanders (Ambystoma opacum) in Virginia. Banisteria, 20, 67-69.

Mitchell, J.C., McGranaghan, L. (2004), An unusually colored eastern milksnake (Lampropeltis triangulum triangulum) from Virginia, with notes on her offspring. Banisteria, 24, 49-50

Nakaya, K. (1973), An albino zebra shark Stegostoma fasciatum from the Indian Ocean, with comments on albinism in Elasmobranchs. Jap. J. Ichthyol, 20, 120-122.

Schwartz, F.J. \& Safrit Jr., G.W. (1977), A white Southern stingray, Dasyatis americana, (Pisces, Dasyatidae), from Pamlico Sound, North Carolina. Chesapeake Science, 18, 83-84.

Schwartz, F.J. (1959), White cownose ray, Rhinoptera bonasus, from Tangier Sound, Maryland. Maryland Tidew. News, 15, 12.

Teixeira, S.F. \& Araújo, M.L. (2002), First record of albinism in the smooth dogfish Mustelus schimitti, 1939 (Carcharhiniformes: Triakidae) from Southern Brazil. Braz. Arch. of Biol. and Tech. 45 (2), 241-243.

Unrine, J. M., Jagoe, C.H., Hopkins, W.A. \& Brant, H.A. (2004): Adverse effects of ecologically relevant dietary mercury exposure in southern leopard frog (Rana sphenocephala) larvae. Environ. Toxicol. Chem., 23, 102108.

Watkins-Colwell, G.J. (2002): A partial Albino northerm Red-Bellied Snake from Vermont. Northeast. Nat. 9, 221224.

Received: May 21, 2007; Revised: February 18, 2008; Accepted: July 09, 2009. 